\title{
Por mais Paulo Freire e menos Escola sem Partido
}

\author{
Márden de Pádua Ribeiro*
}

\begin{abstract}
Resumo
O artigo é uma reflexão teórica fruto de análise bibliográfica da obra de Paulo Freire e enfatiza o conceito de diálogo, compreendido como elemento central de uma pedagogia dialógica freireana. Através do desenvolvimento deste conceito ao longo da obra freireana, o artigo defende que a teoria de Paulo Freire jamais pode ser associada a um viés de doutrinação e manipulação. O trabalho se contrapõe aos argumentos dos apoiadores do Movimento "Escola sem Partido" que enxergam em Paulo Freire o responsável pela suposta doutrinação recorrente nas escolas brasileiras. Para tal, o trabalho recorre aos argumentos de apoiadores do Movimento, bem como manifestações em redes sociais que se pautam pela crítica voraz ao pensamento freireano, visando refutar tais argumentações.

Palavras-chave: Diálogo; Paulo Freire; Escola sem Partido.
\end{abstract}

\section{For more Paulo Freire and less School without Party}

\begin{abstract}
This article deals with a theoretical reflection, fruit of a bibliographical analysis of Paulo Freire's work, having as a theme the concept of dialogue, understood as the central element of a dialogical pedagogy. Through the development of this concept throughout Freire's work, the article argues that Paulo Freire's theory can never be associated with a bias of indoctrination and manipulation. Thus, the work contrasts with the arguments of the supporters of the Movement without the Party and other conservative sectors, who see Paulo Freire, responsible for the alleged recurrent indoctrination in Brazilian schools. To this end, the paper uses the arguments of supporters of the Movement, as well as manifestations in social networks that are based on the voracious criticism of Freirean thought. Finally, in order to refute such arguments.

Keywords: Dialogue; Paulo Freire; School without a Party.
\end{abstract}

\section{Introdução}

O presente artigo trata-se da centralidade do conceito de diálogo como uma das mais fundamentais contribuições da teoria de Paulo Freire para a Educação. Realiza, para tanto, uma reflexão teórica através de levantamento bibliográfico da obra freireana, no intuito de analisar o diálogo em suas distintas obras, diretamente na fonte, isto é, sem o auxílio de comentadores, para defender o diálogo como elemento central imerso em uma concepção pedagógica que crê no potencial emancipador da educação. Sendo assim, o conceito de diálogo na obra freireana será o eixo central do trabalho, entendendo a obra freireana como uma Pedagogia do diálogo.

O diálogo em Freire tem um alvo: a relação educador e educando no processo dialógico de educar e ser educado, transformar e ser transformado. O educador, situado em espaço educacional formal ou não, ciente de sua tarefa político-pedagógica, tem em Paulo Freire uma epistemologia voltada para uma concepção de educação e de mundo, comprometida com a

\footnotetext{
*Endereço Eletrônico: mardendepadua@ yahoo.com.br
}

educação popular, com a lógica dos oprimidos, buscando no sujeito, sua capacidade de "ser mais", em prol da superação da condição de dominação e de uma realidade desigual e injusta.

Trazer o pensamento de Paulo Freire neste artigo é defender uma educação comprometida com a perspectiva dos oprimidos, marginalizados e excluídos. É pensar uma educação com esses sujeitos e não para eles. Daqueles que, na luta, moldam suas vidas e vêem na educação uma oportunidade e uma esperança. Comprometer-se com uma educação transformadora é condição básica para docência de orientação freireana. Transformar aqui deve ser entendido no sentido crítico, de não naturalizar nem aceitar as desigualdades sociais como um fato dado, pelo contrário, percebê-las como um processo histórico de consolidação de alguns, em detrimento do silenciamento de outros.

O contexto inspirador do presente artigo é o atual momento político vivido pelo Brasil, que torna a obra freireana mais atual do que nunca. Tempos políticos instáveis, de descrédito na esperança e nítidas sensações de retrocesso por parte de um governo, não conduzido pelo voto, mas faminto por 
reformas e medidas não dialogadas com a sociedade civil mediante urnas e/ou debates públicos. Nesse sentido, procuramos resgatar, desde as manifestações de junho de 2013 no Brasil, movimentos conservadores que em muitos momentos escolheram Paulo Freire como alvo, acusando-o de ser uma espécie de mentor da doutrinação ideológica que impera na educação brasileira. Tais acusações, evidentemente sem nenhum componente científico, passaram a vigorar consolidadamente em setores da Direita, e serviram de pretexto, por exemplo, para consolidação do movimento "Escola sem Partido", que deu origem a realização de um anteprojeto de lei, levado adiante em alguns Estados via câmaras estaduais, e em nível federal, especialmente pelo Projeto de Lei 196 do senador Magno Malta.

Recentemente, a partir das manifestações de junho de 2013 no Brasil, setores distintos da sociedade foram às ruas dizer suas palavras, propagar suas bandeiras e faixas. Setores conservadores expressaram sua ira em relação à teoria freireana a partir de cartazes com os dizeres: "Basta de Paulo Freire!" (Figura 1). Tais dizeres traziam o descontentamento com o que chamavam de "educação ideológica", promovida nas escolas brasileiras. As redes sociais, nesse sentido, transformaram-se em fértil terreno para a disseminação do ódio em relação a Freire, e de manifestações diversas acerca de sua obra, revelando não raramente uma ignorância explícita.

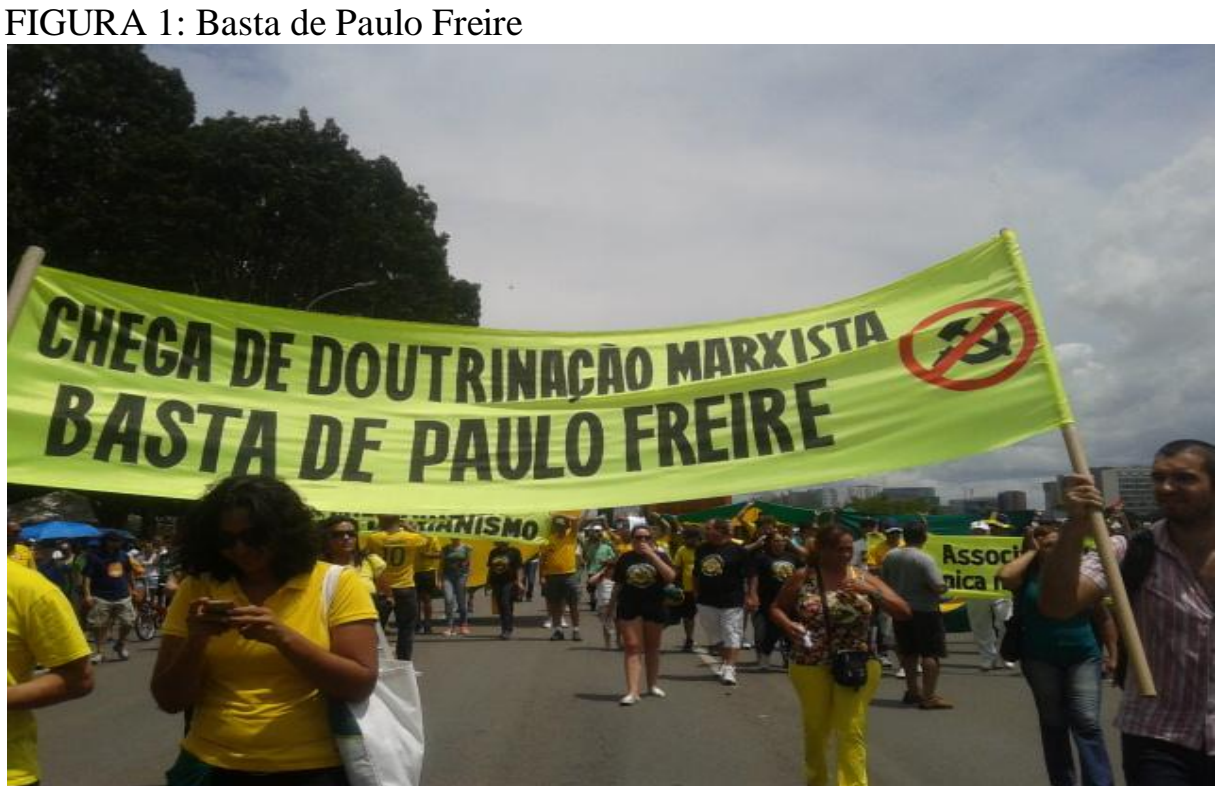

Fonte: http://www.revistaforum.com.br/wp-content/uploads/2015/03/paulo-freirefaixa-protesto.jpg

Uma verificação no YouTube nos revela uma série de vídeos em que pessoas resolvem opinar negativamente a respeito da obra freireana ${ }^{1}$. Analisando os vídeos mais acessados, observamos primeiramente que o número de visualizações, ainda que os vídeos tenham sigo gravados em datas distintas, sempre paira em torno das trinta mil. Número considerável, embora não acachapante, e quase equivalente, o que nos permite inserir que talvez esse seja o nicho virtual daqueles que não toleram a obra freireana, independente de a conhecerem. Conhecer a obra, nesse contexto, nem sempre é regra.

Analisando os três vídeos mais acessados, percebemos os seguintes pontos em comum: Paulo Freire seria o ideólogo do comunismo e, portanto, o responsável pela doutrinação de esquerda especialmente nas escolas públicas brasileiras já há três décadas, no mínimo. Fora isso, ele também é "adorador de Che Guevara"; "admirador do stalinismo"; e "ideólogo do Partido dos Trabalhadores". Concluímos nesses discursos que pouco importa se Freire nunca elogiou Stálin em sua obra, nem se o PT nasceu bem depois de suas incursões bibliográficas. Em relação a Guevara, sem dúvida Paulo Freire nutria por ele grande admiração, enxergando na figura de "Che" um revolucionário que acreditava em sua utopia, na 
busca por um mundo mais justo compactuado pelos oprimidos.

Retomando a questão de Stalin, repetido inúmeras vezes nos vídeos mencionados, vale a pena resgatarmos uma passagem da obra Pedagogia da Esperança, que comprova o modo coerente como Freire sempre lidou com sua ideologia: criticando autoritarismo de direita e de esquerda, se posicionando sempre a favor da democracia, da liberdade e do diálogo.

Para mim, pelo contrário, o que não prestava na experiência do chamado "socialismo realista", em termos preponderantes, não era o sonho socialista, mas a moldura autoritária - que o contradizia e de que Marx e Lênin também tinham sua culpa e não apenas Stalin -, assim como o positivo na experiência capitalista não era e não é o sistema capitalista, mas a moldura democrática em que ele se acha.

Nesse sentido também o esfacelamento do mundo socialista autoritário - que, em muitos aspectos, vem sendo uma espécie de ode à liberdade e vem deixando tantas mentes, antes bem comportadas, estupefatas, atônitas, desconcertadas, perdidas - oferecem-nos a possibilidade extraordinária, se bem que difícil, de continuar sonhando e lutando pelo sonho socialista, depurando-se de suas distorções autoritárias, de seus desgostos totalitários, de sua cegueira sectária (FREIRE, 1992, p.43).

Defendemos que tais cartazes e vídeos não devem conhecer sequer a premissa básica da obra freireana: toda a educação e todo o conhecimento são ideológico, nunca neutro. O que não quer dizer que tenha de ser panfletário ou, nas palavras de Freire (1992): sectário.

Mais recentemente, o movimento "Escola sem Partido", criado sob a premissa de que há uma doutrinação de esquerda nas escolas, tem buscado via Congresso Nacional, a alteração da Lei de Diretrizes e Bases da Educação Nacional, inserindo o dever da docência alcançar a neutralidade, sob o pretexto de impedir a manipulação dos estudantes brasileiros. O projeto em seus artigos e incisos, busca conter a suposta manipulação dos docentes brasileiros:

Art. $2^{\circ}$. A educação nacional atenderá aos seguintes princípios:

I - neutralidade política, ideológica e religiosa do Estado; [...]

$\mathrm{V}$ - reconhecimento da vulnerabilidade do educando como parte mais fraca na relação de aprendizado; $[\ldots]$
VII - direito dos pais a que seus filhos recebam a educação religiosa e moral que esteja de acordo com as suas próprias convicções. [...]

Art. 5'. No exercício de suas funções, o professor:

I - não se aproveitará da audiência cativa dos alunos, para promover os seus próprios interesses, opiniões, concepções ou preferências ideológicas, religiosas, morais, políticas e partidárias; [...]

III - não fará propaganda político-partidária em sala de aula nem incitará seus alunos a participar de manifestações, atos públicos e passeatas; [...] $\mathrm{V}$ - respeitará o direito dos pais dos alunos a que seus filhos recebam a educação religiosa e moral que esteja de acordo com as suas próprias convicções (ESCOLA SEM PARTIDO, 2017).

O anteprojeto de lei do movimento "Escola sem Partido" que tem servido de inspiração para diversos projetos de lei em âmbito estadual e federal, tenta garantir uma suposta neutralidade no ato educativo, amarrando a educação escolarizada às convicções dos pais. Além disso, preconiza que o educador não pode promover suas opiniões ou preferências, nem incitar alunos a participar de manifestações ou demais atos públicos. Não é foco do presente artigo discutir as ambiguidades, superficialidades, contradições presentes no projeto, e sim, articular tais idéias com a temática aqui proposta.

É nesse sentido que a teoria freireana é utilizada como parâmetro definidor de tudo que significa uma educação "doutrinatória". Os partidários do movimento "Escola sem Partido" enxergam em Freire a expressão máxima da doutrinação e por diversas vezes o utilizam como exemplar concreto de tal ação. Em um debate no canal Futura, o criador do Movimento "Escola sem Partido", o advogado Miguel Nagibe, disse textualmente que "Paulo Freire não conhecia direito constitucional. Ele era o pedagogo do PT. Ele utilizou toda sua pedagogia progressista pra promover os interesses do partido." Após ser corrigido pelo apresentador, que ressaltou que Freire cronologicamente é anterior ao PT, Miguel Nagibe continuou afirmando sua teoria ${ }^{2}$, desconsiderando também que Paulo Freire, advogado de formação, fatalmente conhecia noções de direito constitucional.

Apoiadores do Movimento "Escola sem Partido" utilizam Paulo Freire em alguns momentos em tom jocoso, já em outros momentos tentam uma análise de sua obra, ainda que feita de forma superficial, atrelando a Freire algo que o próprio 
sempre condenou: a doutrinação. Mas para o Movimento, a pecha pregada em Paulo Freire serve como estratégia de marketing para a própria divulgação do ideário defendido pelos adeptos do "Escola sem Partido". Desse modo, nas redes sociais, em debates públicos, ou nos artigos contidos no site do Movimento, não raramente
Paulo Freire está lá, sempre criticado de forma apoteótica, com frases de efeito e pouca análise. É sob esse prisma que Paulo Freire se torna "Paulo Nosferatu Freire" em uma postagem da rede social do idealizador do Movimento Escola sem Partido, Miguel Nagibe (Figura 2).

FIGURA 2: Paulo Nosferatu Freire

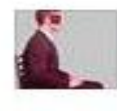

Miguel Nagib

30 de agosto às $17: 14$ -

Conde Gramsci, o vampiro que vampiriza a educação brasileira, com a ajuda de Paulo Nosferatu Freire, pode estar com seus dias contados.

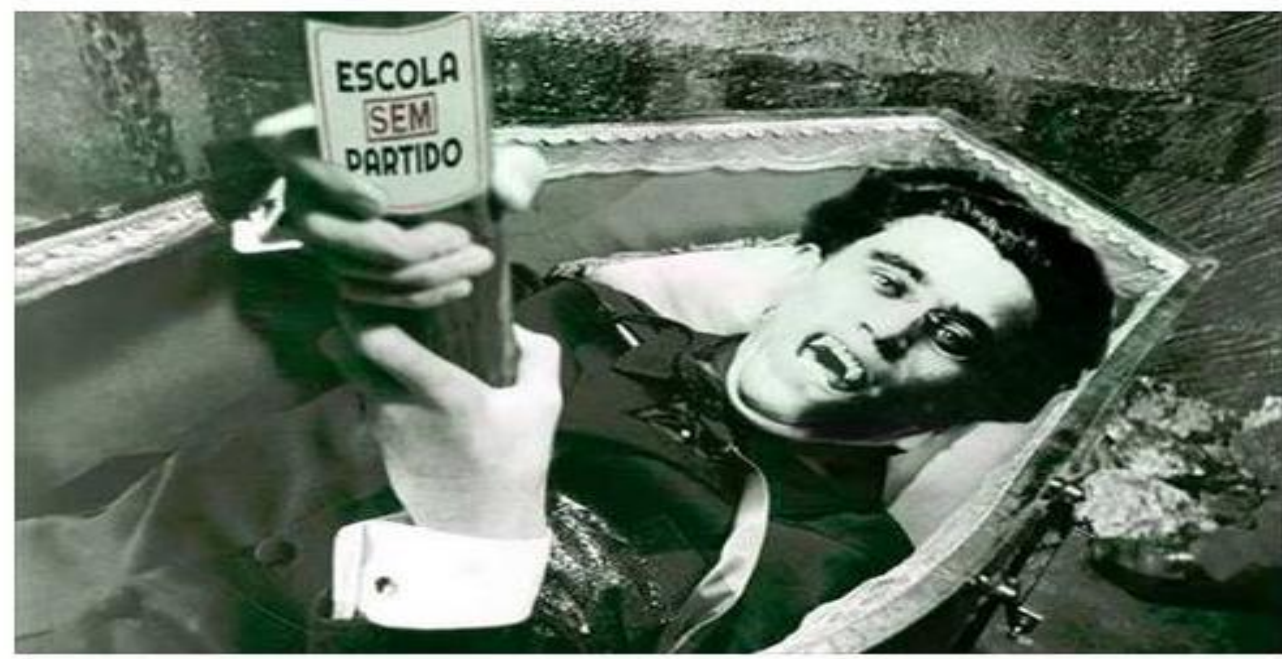

387 curtidas 23 comentários 98 compartilhamentos

Curtir

Compartilhar

Fonte: https://liberdadeparaensinar.files.wordpress.com/2015/09/imagem-3.jpg Acessado em: 11 de abril de 2017.

$\mathrm{Na}$ rede social oficial do Movimento "Escola sem Partido", sempre que é postado algum vídeo supostamente comprovando alguma doutrinação exercida por docentes (filmados em segredo, sem autorização, em suas práticas), a descrição do vídeo eleva o nome de Freire, ainda que o conteúdo em si do vídeo em nada faça menção ao autor. Assim, Paulo Freire é semanticamente útil ao Movimento, e se torna adjetivo pejorativo associado a práticas doutrinatórias nas escolas (Figuras 3 e 4). 
FIGURA 3: Facebook do "Escola sem Partido"

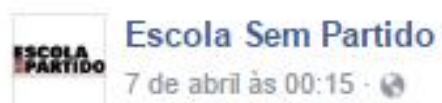

\section{COVARDIA SEM LIMITES: A TARA PAULOFRÊNICA DA EDUCAÇÃO BRASILEIRA}

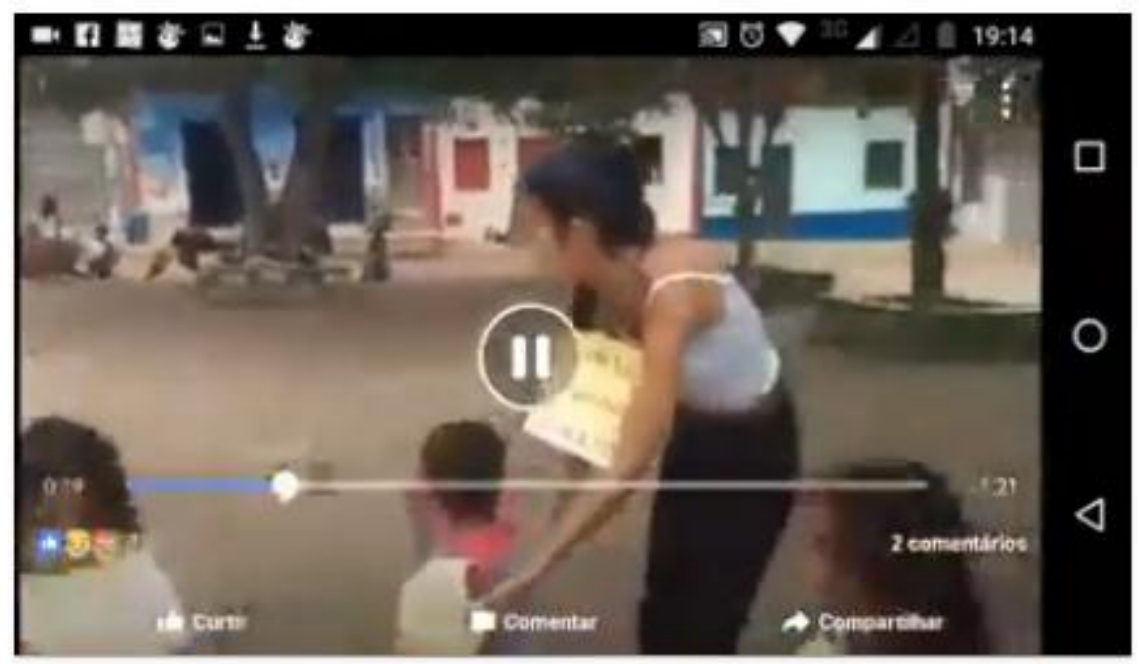

44 mil visualizaçöes

It Curtir Comentar $\Rightarrow$ Compartilhar

Fonte: nossa pesquisa

FIGURA 4: Facebook do "Escola sem Partido"

\section{5scomb Escola Sem Partido}

ESSE É O RETRATO DA PAULOFRENIA EDUCACIONAL BRASILEIRA. VEJAM A QUE PONTO CHEGOU O USO POLITICO-PARTIDÁRIO DAS ESCOLAS. É INACREDITÁVEL.

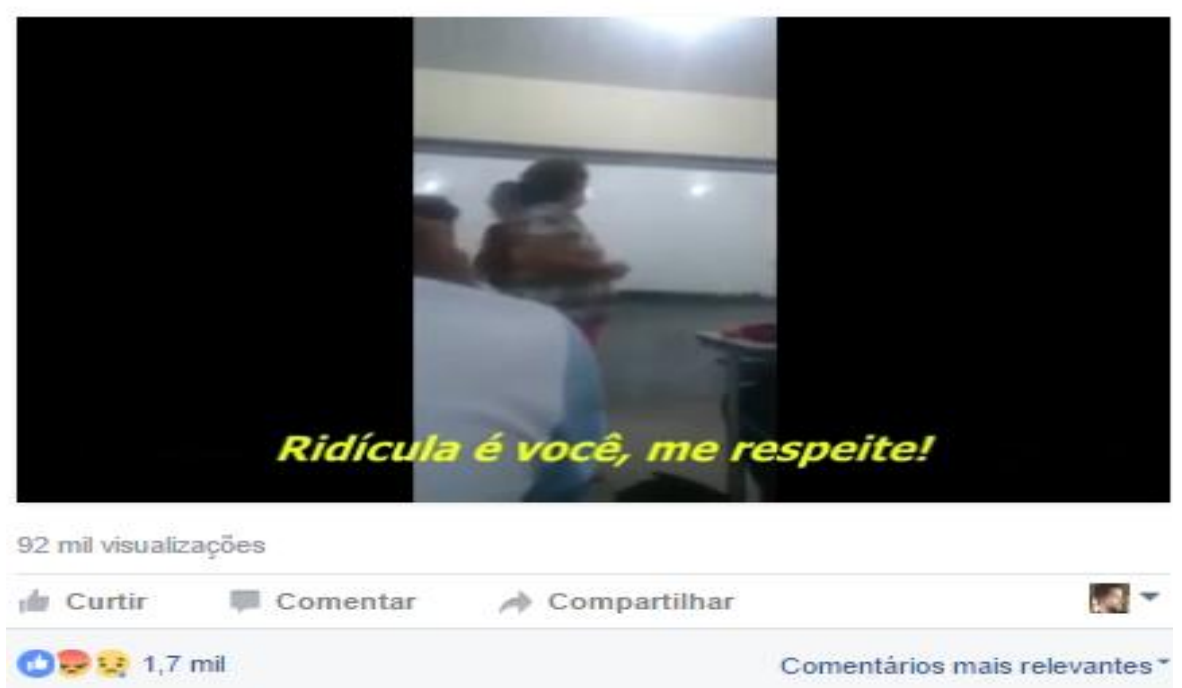

Fonte: nossa pesquisa 
O que as duas imagens têm em comum? Ambas servem como suposta denúncia de doutrinação nas escolas e nas suas descrições, Paulo Freire aparece como "tara paulofrênica" e "paulofrenia educacional"; neologismos utilizados para pregar em Freire o rótulo da manipulação, da doutrinação, associando-o a figura do vilão-mor da educação brasileira. Afinal, por que Paulo Freire incomoda tanto?

A crítica desses setores conservadores à teoria freireana carrega a injusta acusação de que Paulo Freire é um doutrinador, quando, na verdade, toda sua obra possui em si um valor essencial: o diálogo. Os setores conservadores que atacam a teoria freireana possuem imensa dificuldade de produzir críticas com um mínimo de fundamento científico capaz de refutar e contrapor a teoria freireana. Limitam-se à acusação de doutrinação negando a dialogicidade, certamente, marca central de suas obras.

Não são raros os artigos publicados no site do movimento, cujo nome de Freire aparece sempre sob acusação de ser uma espécie de menor de uma educação comunista doutrinatória presente nas escolas brasileiras. Em que pese que os artigos tentem argumentar com um pouco mais de profundidade suas críticas à obra freireana, ainda assim, não conseguem escapar de generalizações imprecisas e vagas.

Sempre com retórica virulenta, palavras de impacto e expressões irônicas e estereotipadas, os artigos conseguem chamar atenção daqueles que preferem retórica à análise, mas não conseguem tecer argumentos que busquem corroborar as próprias críticas que fazem. Dos quinze artigos analisados por nós, todos retirados do site do movimento, apenas um, intitulado "Pedagogia do Opressor", esboça timidamente uma contraargumentação se utilizando de três passagens literais da obra de Freire para justificar as críticas do artigo. Nos demais, há um emaranhado de frases de efeito que carecem de um mínimo de solidez argumentativa para serem levadas a sério, em uma discussão que se pretende construtiva.

Nos artigos encampados pelo movimento, podemos encontrar todo tipo de generalização de efeito: "Paulo Freire, que prega a liberdade, mas cultua totalitarismos. Pedagogia do Oprimido, [é] uma espécie de manual de autoajuda marxista" (STERN, 2015, s.p). Em outra generalização que não apresenta nenhuma argumentação posterior, Freire é acusado de inspirar o preconceito linguístico: "O reducionismo pedagógico é o grande legado de Paulo Freire. Juntando-se ao "construtivismo pós-piagetiano", ele inspirou o "preconceito linguístico", que vilipendia a norma culta do idioma" (STERN, 2015, s.p).

Tais críticas se somam a muitas outras, sempre partindo da premissa de que há um domínio marxista na educação brasileira: "É a visão marxista que domina soberana em nossas escolas e que se revolta quando confrontada com posturas mais conservadoras." (RODRIGUES, 2015, s.p). Em um artigo em específico, é fornecida a definição da função da educação, sob o manto da aparente neutralidade: "A educação é um processo entre ensinar e aprender, tem finalidade social, serve para a manutenção da sociedade" (RODRIGUES, 2015, s.p). É curioso constatar que para os apoiadores do "Escola sem Partido", uma educação que vise a manutenção da sociedade é encarada para eles como uma função neutra, objetiva. Não se dão conta de que pensar a educação nesse viés é também tomar partido, ou seja, se posicionar diante da educação e do mundo, e, portanto, não possuir qualquer tipo de neutralidade. Assim, para o movimento, neutralidade é tudo aquilo que serve manter o status quo enquanto manipulação seria toda e qualquer Pedagogia cujo objetivo seria questionar, problematizar e transformar a sociedade.

Talvez a expressão mais simbólica da agressividade somada à superficialidade das críticas feitas à teoria freireana, por parte de apoiadores do "Escola sem Partido", pode ser observada na passagem do artigo de autoria de Reinaldo Azevedo, conhecido colunista da Revista Veja. Nesse trecho estão contidos todos os fundamentos das críticas: superficialidade, palavras de impacto, agressividade, ausência de contra-argumentação e ironia.

A escola brasileira acabou, morreu, foi para o ralo. Virou lixo. Foi vítima de "progressiste" aguda. A "progressiste" é uma infecção provocada por um vírus cuja letalidade se deve à mente torta de Paulo Freire, que muita gente considera um santo. Não é que ele tenha criado o bichinho original. Mas foi quem o espalhou (AZEVEDO, 2014, s.p).

Em tempos cuja sociedade brasileira encontra-se polarizada, dividida em extremos que pouco escutam e muito falam, o diálogo é fundamental e necessário, e encontra na teoria freireana alicerce fundamental. Diálogo pressupõe a escuta e o respeito ao outro, assim como a necessária compreensão de que não existem 
dicotomias de saberes quando se dialoga. É bem verdade que o diálogo freireano, ainda que sob forte componente filosófico-humanizador, integra-se fortemente ao campo educacional.

Desse modo, a justificativa do presente artigo consiste no fato de que a educação é justamente esse potencial de transformação em busca de uma sociedade que dialoga ao invés de disseminar o ódio. Sem dúvida, uma educação sob bases dialógicas freireanas, oferece às sociedades gerações de educandos que percebem no diálogo, a potência máxima da autonomia e da libertação, que pressupõe escuta atenta, amorosidade, rigorosidade metódica e oferta da palavra (FREIRE, 1976, 1983, 1992, 1996, 2013).

A obra freireana se compromete com uma concepção de educação e de mundo, jamais neutra, que denuncia a lógica excludente. Em meio a isso, Freire $(1992,2013)$ sempre fez severas críticas ao educador, que sob o manto revolucionário, acabava por ter ações sectárias, doutrinatórias e bancárias. Assim, Freire $(1992,2013)$ chamava a atenção para o diálogo, justamente como a práxis libertadora dos sujeitos, cujo papel dos educadores não é dizer a palavra para o outro, e sim, com o outro, lerem o mundo e se modificarem a partir de suas distintas leituras.

Aí está uma das tarefas da educação democrática e popular, da Pedagogia da esperança - a de possibilitar nas classes populares o desenvolvimento de sua linguagem, jamais pelo blablablá autoritário e sectário dos "educadores", de sua linguagem, que, emergindo da e voltando-se sobre sua realidade, perfile as conjecturas, os desenhos, as antecipações do mundo novo. Está aqui uma das questões centrais da educação popular - a da linguagem como caminho de invenção da cidadania (FREIRE, 1992, p.20, grifos do autor?).

A estratégia metodológica utilizada no presente artigo, portanto, é estabelecer uma análise bibliográfica de algumas obras de Paulo Freire, buscando nelas o diálogo como conceito crucial. A escolha dessas obras obedeceu ao critério de abarcar as diferentes fases pelas quais Freire passou em sua obra, na perspectiva dos distintos "Freires" que nos fala Scocuglia (1999).

As seguintes obras foram escolhidas, dentro do critério mencionado: Educação como Prática de Liberdade, Pedagogia do Oprimido, Ação Cultural para Liberdade, Diálogo e Conflito, Medo e Ousadia, Educação e Mudança, Pedagogia da
Esperança e Pedagogia da Autonomia. Acreditamos que com essas obras, o conceito de diálogo pode ser abordado em sua profundidade garantindo ainda a compreensão de pequenas nuances de mudança pelas quais Freire passou no desenvolvimento deste conceito.

A obra de Paulo Freire, longe de ser sectária, panfletária, é, ao contrário, um convite ao diálogo e ao respeito amoroso às diferenças, sem deixar de se comprometer com um projeto societário engajado na luta dos oprimidos, na busca por uma sociedade menos injusta, menos desigual, mas também no máximo respeito às escolhas dos educandos: "[...] Mas se ele é coerente com essa opção democrática, ele necessariamente - não escondendo sua opção - respeita a capacidade de optar que o educando deva ter, e até estimula essa capacidade." (FREIRE, 1984, p.87).

Para Freire (1983), mudança e transformação exigem engajamento nas lutas posicionando-se a favor dos oprimidos. Longe de ser sectário, engajar-se não significa num ativismo superficial, destinado apenas a imposição de visões de mundo, fechando-se ao diálogo e abrindo-se ao autoritarismo. O ativista sectário para Freire (1967) é aquele que possui dificuldade em ir além do superficial, e acaba fixando-se em meias verdades e clichês. O educador engajado reflete sua ação prática, o educador sectário age sem problematizar sua ação.

Para se pensar a educação para a transformação, portanto, é necessário, como dito, engajar-se, ou seja, exige do educador um compromisso, que para Freire $(1983$, p.19) é "próprio da existência humana, só existe no engajamento com a realidade, de cujas águas os homens verdadeiramente comprometidos ficam molhados e ensopados". Transformar então é sempre criação humana, é ser sujeito de sua ação, significa interferir na estrutura da sociedade.

A teoria freireana é frequentemente mencionada em diversos trabalhos, seja como perfumaria (STRECK, 2014), seja como elemento teórico central do trabalho. Contudo, faz sentido nos tempos atuais, insistir em Freire na educação? A nosso ver, certamente sim. Importante referência para a formação de professores, Antônio Nóvoa defende a importância da teoria freireana:

A vida e a obra de Freire estão inscritas no imaginário pedagógico do século $\mathrm{XX}$, constituindo uma referência obrigatória para várias gerações de educadores. [...] As propostas por ele lançadas foram sendo apropriadas por 
grupos distintos, que as relocalizaram em vários contextos sociais e políticos. [...] A partir de uma concepção educativa própria, que cruza a teoria social, o compromisso moral e a participação política, Paulo Freire é, ele próprio, um patrimônio incontornável da reflexão pedagógica atual. A sua obra funciona com uma espécie de consciência crítica, que nos põe em guarda contra a despolitização do pensamento educativo e da reflexão pedagógica (NÓVOA apud SAUL; SILVA, 2009, p. 231).

$\mathrm{Na}$ contramão da lógica conservadora, objetiva-se aqui resgatar o pensamento freireano, se contrapondo ao conservadorismo que depende da manutenção do status quo para legitimação de sua condição de classe dominante. Contrapõe-se também ao conservadorismo que habita também o oprimido, que, alienado da sua condição de opressão, hospeda em si a mentalidade opressora, e muitas vezes não percebe a necessidade da transformação social. Assim, o presente artigo perpassará pela obra freireana ressaltando o diálogo como a temática central na educação em busca do inédito viável: uma sociedade democrática e aberta às diferenças.

\section{O diálogo em Paulo Freire}

Durante o binômio 2014-2016 a Rede Freireana de Pesquisadores, tem realizado uma pesquisa intitulada: "Paulo Freire na atualidade: legado e reinvenção: análise de sistemas públicos de educação a partir dos anos 1990", coordenada pela Prof. ${ }^{a}{ }^{\mathrm{a}}$. Ana Maria Saul, do Programa de PósGraduação em Educação: Currículo da Pontifícia Universidade Católica de São Paulo (PUC-SP). Nesta pesquisa, são analisadas dissertações e teses espalhadas pelo Brasil no intuito de perceber como $\mathrm{o}$ pensamento freireano tem sido reinventado $\mathrm{e}$ ressignificado à luz de seus conceitos.

Neste levantamento realizado a partir do Banco de Teses e Dissertações da CAPES, identificamos inúmeros trabalhos que apresentaram o referencial freireano como central. Ao todo, 72 (setenta e dois) trabalhos, entre dissertações e teses, foram analisados e destes, escolhemos 35 (trinta e cinco) para uma análise aprofundada, entendendo que se tratava dos trabalhos que traziam o referencial freireano de forma mais completa.

A partir das análises, uma categoria conceitual da obra freireana se fez presente de modo especial: o diálogo. Foi possível perceber sua importância, sobretudo para trabalhos ligados ao currículo e à formação de professores. E, é neste sentido, que a categoria diálogo permeia a práxis docente, preocupada com a sua relação com os (as) alunos (as) mediatizada pelo mundo, que Freire se faz presente em teses e dissertações que tratam de assuntos extremamente diversos, tais como: Astronomia, Artes, Ciências, Direitos Humanos, Educação Ambiental, Educação Física, Ensino Médio, Equoterapia, Espectroscopia, Etnomatemática e Física. São pesquisas que tem o foco na relação entre educador (a)-educandos (as) em que o diálogo freireano se faz presente como categoria conceitual que abarca as concepções pedagógicas dos trabalhos.

Guedes (2012, p.55) fornece explicação que vai ao encontro com o que encontramos:

(...) o diálogo como categoria fundante do pensamento de Paulo Freire pode orientar as questões que permeiam a construção do currículo. Dentre essas orientações, destacamos o diálogo não apenas quando o professor e o estudante se encontram em situação pedagógica, mas também quando se busca o conteúdo programático da educação, ou seja, em torno do objeto do conhecimento que o professor vai dialogar com os estudantes.

Nas palavras de Menezes e Santiago, o diálogo na obra freireana é assim analisado:

O diálogo, em Paulo Freire, favorece o pensar crítico-problematizador das condições existenciais e implica uma práxis social na qual ação e reflexão estão dialeticamente constituídas. A liberdade de homens e mulheres expressarem as suas ideias, o que pensam e por que pensam, junto com o outro, provoca a interação e a partilha de diferentes concepções que impulsionam um pensar críticoproblematizador da realidade. Esse movimento gera a necessidade de intervenção no nível das ações, visto que, na perspectiva freireana, a palavra verdadeira é práxis social comprometida com a ação transformadora (MENEZES; SANTIAGO, 2014, p. 52).

Nestas pesquisas foi possível identificar a importância da obra Pedagogia da Autonomia: saberes necessários à prática educativa, como uma das obras mais utilizadas para referenciar o que Paulo Freire teorizava acerca do diálogo. Contudo, no presente artigo caminharemos pelo diálogo ao longo do pensamento freireano e não somente em uma obra específica. 
$\mathrm{O}$ intuito de trazer essa pesquisa da Rede Freireana de Pesquisadores é para embasar o que alguns teóricos já afirmam: de que o conceito de diálogo é crucial na obra freireana e condição básica para a compreensão de sua epistemologia. O diálogo em Freire ultrapassa a mera noção metodológica do fazer docente; vai além, diz de uma concepção de mundo e de homem que via diálogo, mediado pelo mundo, encontra o outro e lhe oferta a palavra. Em suma, o diálogo freireano é um convite a alteridade, ao respeito irrestrito às diferenças e ao exercício da escuta; valores que atualmente são urgentes em nossa sociedade.

Scocuglia (1999), autor referência no que diz respeito à análise da obra freireana, também conclui em seu artigo que o diálogo é a categoria central do pensamento freireano. No dicionário a respeito da obra de Paulo Freire, Zitkoski (2010, p.117), ao escrever o verbete relacionado ao diálogo, afirma que a educação humanistalibertadora de Paulo Freire, "tem no diálogo/dialogicidade uma das categorias centrais de um projeto pedagógico crítico, mas propositivo e esperançoso em relação ao futuro".

Entretanto, o modo pelo qual Paulo Freire construiu seu conceito de diálogo foi algo que se desenvolveu ao longo de sua obra, sem, no entanto, perder em momento nenhuma a premissa da escuta, da não hierarquização dos saberes e de seu potencial emancipador. Freire passeou por um Brasil inserido em conflitos políticos graves, da década de cinquenta, passando pelo regime militar e o consequente exílio, até as delícias e frustrações da redemocratização, em que experimentou por curto tempo a experiência de ser Secretário de Educação de São Paulo na prefeitura de Luíza Erundina. Nesse ínterim, repensou e ressignificou sua obra, flexibilizou sua influência marxista e aderiu a algumas contribuições pós-modernas (FREIRE, 1992).

Scocuglia (1999) alerta que anteriormente à Pedagogia do Oprimido, a visão de Paulo Freire em relação ao diálogo carregava um viés idealista, fruto do humanismo cristão que o influenciou fortemente. Assim, sua noção de diálogo não caminhava para o conflito entre classes, e sim, para uma tentativa de consenso em torno da nação, num tom otimista de harmonia social tendo o diálogo como condição fundamental. Assim, gradativamente, "a questão dialógica é mergulhada nas lutas sociais e, cada vez mais, categorizada como parte do que o autor denomina ação cultural para a libertação". (SCOCUGLIA, 1999, p.33). Preocupado com o romantismo/idealismo inevitavelmente embutido na dialogicidade, Freire (1984, p.151) adverte:

(...) talvez se pense que, ao fazermos defesa deste encontro dos homens no mundo para transformá-lo, que é o diálogo, estejamos caindo numa ingênua atitude, num idealismo subjetivista. Não há nada, contudo, de mais concreto e real do que os homens no mundo e com o mundo. Os homens com os homens, como também alguns homens contra os homens, enquanto classes que oprimem e classes oprimidas.

Paulo Freire propõe o papel da educação, escolar ou não, voltada a promover uma prática político-pedagógica cujo sujeito, consciente de seu processo de contínua humanização, faz-se crítico no ato de interagir com o mundo. Essas reflexões são cruciais para se pensar o sentido do diálogo na educação, tendo como ponto de partida a concepção de sujeito e mundo para Paulo Freire.

Já em sua primeira obra, Freire (1967) enfatiza sua práxis através da importância da comunicação como uma ação eminentemente humana. Comunicar aqui, entendido como uma apropriação do mundo, passível de ser conhecido pelos sujeitos. Comunicar envolve ainda a não anulação do outro, ou seja, pressupõe aceitação irrestrita do outro, que no mundo, interage comigo, e mutuamente se ressignificam.

Educar nesse sentido, para Freire (1967) diz de uma práxis de liberdade/libertação, cujo diálogo é pressuposto central na possibilidade de libertação dos oprimidos, através de uma tomada de consciência de suas lutas, e deu estar no mundo. O diálogo, quando humanizador, com o outro, visa resgatar os oprimidos para a humanização, que segundo Freire (1976) é o destino dos sujeitos.

Nesse momento, embora o foco tratava-se da alfabetização de adultos, o diálogo aparecia em seu pensamento como uma categoria crucial, e posteriormente, alçaria como o ponto chave de sua epistemologia. Escrita no exílio, a obra Pedagogia do Oprimido é um clássico mundial, e nela, o diálogo é trabalhado por Paulo Freire de maneira profunda e central. Nela, Freire (2013) centraliza o papel do diálogo para uma educação libertadora. Indo além do que já havia produzido anteriormente.

A educação e a pedagogia não deixaram de realizar-se via diálogo, não deixaram de priorizar $\mathrm{o}$ ato de conhecimento, a busca da consciência crítica. Mas, o que antes era predominantemente psico-pedagógico, passou a 
ser prioritariamente político-pedagógico. Isso sem anular as preocupações psico-sociais que embasam suas propostas desde seus primeiros escritos de base escolanovista popular (SCOCUGLIA, 1999, p.67).

Pelo diálogo, observamos o mundo como um processo inconcluso, em constante transformação, e nos transformamos, mediatizados pelo mundo, na medida em que pela palavra, conhecemos o outro. Essa relação eu-outro, dialógica, é também dialética para Freire (2013). O diálogo para Freire $(1992 ; 2006 ; 2013)$ impulsiona um pensar crítico, que problematiza a relação humana no mundo. O diálogo diz o mundo, através da palavra do sujeito e de seu olhar, que é sempre comprometido com uma práxis social, voltada para a humanização. Essa práxis social, revestida de palavras de mundo, imbrica-se em uma açãoreflexão, dialeticamente constituída. "Não há palavra verdadeira que não seja práxis. Daí que dizer a palavra verdadeira seja transformar o mundo" (FREIRE, 2013, p.44).

Práxis pra Freire $(1992 ; 1997 ; 2006 ; 2013)$ diz respeito à estreita relação que há entre um modo de interpretar determinada realidade e a consequente prática que resulta dessa compreensão, gerando sempre uma ação que interfere na realidade, transformando-a. Opõe-se, portanto, á domesticação alienante, ao induzir uma ação precedida pela conscientização, de seu estar no mundo, de seu apropriar-se do mundo. $\mathrm{O}$ sujeito ao dizer sua palavra, age para transformar sua realidade. Práxis é, em síntese, palavra-ação, calcada no diálogo transformador.

Percebe-se claramente, portanto, que associar o pensamento freireano com a manipulação e doutrinação é desconhecer gravemente o fundamento epistemológico dialógico de sua obra. É negar que Paulo Freire sempre enxergou no diálogo, o exercício democrático e ao mesmo tempo transformador da educação. Não há espaço para posturas sectárias e autoritárias que depositam bancariamente no outro, as verdades supostas. Ao contrário, como afirma Freire (2013), ninguém liberta ninguém, o que ocorre, é um processo conjunto e dialético de emancipação, via diálogo pedagógico. Por essa razão, a pedagogia freireana é essencialmente dialógica.

$\mathrm{Na}$ teoria freireana, encontramos um pensamento inquieto em torno do homem, de suas relações com o mundo e com o outro. Tornar-se homem, para Freire (2013), é referir-se ao homem em situação concreta da realidade, em outras palavras, é compreender sua condição construída historicamente. Nesse sentido, Freire (1992; 1996; 1997; 2006; 2013) defende como vocação deste homem, sua busca constante de ser mais, ou seja, compreende o ser humano em uma espécie de devir, de vir-à-ser, jamais descolado de sua realidade, e jamais ancorado em uma completude. Os seres humanos, portanto, são seres de busca, tomando como ponto chave o processo de humanização. Perceber a existência humana na perspectiva de ser mais é reconhecer o sujeito sempre em movimento, inconcluso, incompleto, historicamente inacabado.

Desse modo, Para Freire (1992), percebe-se que é na relação que o homem vive com o mundo, na inter-relação entre subjetividade e objetividade, que seu pensamento se constitui. O homem, como ser de relações, desafiado pela natureza, a transforma pelo trabalho, "... e que o resultado desta transformação, que se separa do homem, constitui seu mundo. $\mathrm{O}$ mundo da cultura que se prolonga no mundo da história" (FREIRE, 1992, p. 65).

Esse mundo cultural constitui-se histórico, e media o encontro dialógico entre sujeitos. Nesse sentido, como nos aponta Freire e Shor (1986), o mundo tornado objeto de conhecimento, não se faz finalidade de pensamento, mas mediador de comunicação. O mundo torna-se objeto de reflexão humana por meio da capacidade do homem de objetivá-lo em sua consciência.

Nesse processo, o mundo é (re)construído pela práxis do homem, ancorada em suas necessidades e intenções. $\mathrm{O}$ mundo cultural e histórico é uma realidade em constante processo de transformação. É por esse motivo que Freire contextualiza sua ideia de ser humano, que não se instaura sobre o mundo, mas com o mundo, transformando-o e transformando-se, dialeticamente, sendo que o mundo, ressignificado, se volta problematizado para este homem. Não estando sobre ou dentro do mundo, mas com ele, pois ao transformá-lo, o mundo se volta problematizado para o homem, transformando-o.

Na verdade, não há eu que se constitua sem um não-eu. Por sua vez, o não-eu constituinte do eu se constitui na constituição do eu constituído. Dessa forma, o mundo constituinte da consciência se torna mundo da consciência, um percebido objetivo seu, ao qual se intenciona (FREIRE, 2013, p. 87).

$\begin{array}{llrrr}\text { Para } & \text { Freire } & (1983, & 1984) & \text { o diálogo } \\ \text { constitui-se } & \text { essência de } & \text { uma } & \text { educação } \\ \text { humanizadora } & \text { e se apresenta como um fenômeno }\end{array}$ 
essencialmente humano, realizado pelos sujeitos por meio da palavra-linguagem, a partir de duas dimensões: a ação, (transformadora) e a reflexão, atrelada à conscientização crítica, libertadora. A palavra não deve ser um privilégio de poucas pessoas, mas direito de todos, afinal: "Os homens se fazem pela palavra, no trabalho, na ação-reflexão" (FREIRE, 1996, p.78). Freire (1967) faz uma ressalva, diferenciando sua concepção de diálogo, daquelas elaboradas pelos dois clássicos gregos: Sócrates e Platão:

O intelectualismo socrático - que tornava a definição do conceito como o conhecimento da coisa definida e o conhecimento mesmo como virtude, não constituía uma verdadeira pedagogia do conhecimento, mesmo que fosse dialógica. A teoria platônica do diálogo não conseguiu ir muito mais além de Sócrates, ainda que, para Platão, a "prise de conscience" fosse uma das condições necessárias ao ato de conhecimento e que alcançar a verdade implicasse na superação da "doxa" pelo "logos". Para Platão, porém, a "prise de conscience" não se referia ao que os seres humanos soubessem ou não soubesse ou soubessem equivocadamente em torno de suas relações dialéticas com o mundo. Tinha que ver com o que os seres humanos um dia souberam e de que se esqueceram ao nascer. Conhecer era, pois, relembrar ou recuperar um conhecimento olvidado. A apreensão da "doxa" e do "logos" e a superação daquela por este não se dava na compreensão dialética das relações seres humanos-mundo, mas no esforço de recordar um "logos" esquecido. Para que o diálogo seja o selo do ato de um verdadeiro conhecimento é preciso que os sujeitos cognoscentes tentem apreender a realidade cientificamente no sentido de descobrir a razão de ser da mesma - o que a faz ser como está sendo. Assim, conhecer não é relembrar algo previamente conhecido e agora esquecido. Nem a "doxa" pode ser superada pelo "logos" fora da prática consciente dos seres humanos sobre a realidade (FREIRE, 1967, p.45).

A teoria da ação dialógica supõe uma conscientização da realidade para combater o naturalismo que desconhece a historicidade do ser humano como fazedor de sua própria história. Implica a convicção de que a educação também pode ser espaço de resistência, e não de legitimação das injustiças e desigualdades que cotidianamente nos cercam. Relações dialógicas, conforme aponta Freire (2006) se fundamentam no fato de que os sujeitos são atores de sua própria história, e não vítimas de um determinismo fatalista que os condiciona na existência.

E o que é o diálogo? É uma relação horizontal de A com B. Nasce de uma matriz crítica e gera criticidade. Nutre-se do amor, da humildade, da esperança, da fé, da confiança. Por isso, só o diálogo comunica. E quando os dois pólos do diálogo se ligam assim, com amor, com esperança, com fé um no outro, se fazem críticos na busca de algo. Instala-se, então, uma relação de simpatia entre ambos. Só aí há comunicação (FREIRE, 2013, p.115).

(...) a dialogicidade verdadeira, em que os sujeitos dialógicos aprendem e crescem na diferença, sobretudo, no respeito a ela, é a forma de estar sendo coerentemente exigida por seres que, inacabados, assumindo-se como tais, se tornam radicalmente éticos (FREIRE, 1996, p.35).

Percebe-se claramente o viés da humanização na dialogicidade freireana, cujos sujeitos interagem-se sem condições hierárquicas de saberes, e sem a dimensão autoritária do dialogar "para". O diálogo freireano é condição básica para uma educação comprometida com a humanização dos sujeitos, que mediatizados pelo mundo, passam a pronunciá-lo, modificá-lo. O homem, pelo diálogo, realiza-se não como objeto, e sim como um ser consciente de seu papel político na realidade.

O diálogo em Paulo Freire não pode ser confundido com uma negociação e conflito de interesses, para Freire (1984, 1997, 2013), em uma sociedade de classes o diálogo nessas condições torna-se quase impossível, pode se restringir a espaços específicos, menores, como uma sala de aula, por exemplo, mas jamais no âmbito da sociedade como um todo. O diálogo em Paulo Freire, a partir do desenvolvimento de sua obra, não é mais uma relação consensual e harmônica entre oprimidos e opressores, ele deve servir aos oprimidos, para que superem essa condição de opressão. Como afirma Scocuglia (1999, p.78), “O diálogo, enfatize-se, admitido de início como possibilidade de mediação interclasses é rechaçado como tal e entendido como ação entre os iguais e os diferentes, mas contra os antagônicos nos conflitos sociais".

Por isso, além de relacional e humanizador, o diálogo também é político e transformador:

No processo da fala e da escuta a disciplina do silêncio a ser assumido com rigor e a seu tempo pelos sujeitos que falam e escutam é um sinequa da comunicação dialógica. O primeiro sinal de 
que o sujeito que fala sabe escutar é a demonstração de sua capacidade de controlar não só a necessidade de dizer a sua palavra, que é um direito, mas também o gosto pessoal, profundamente respeitável, de expressá-la. Quem tem o que dizer tem igualmente o direito e o dever de dizê-lo. É preciso, porém, que quem tem o que dizer saiba, sem sombra de dúvida, não ser o único ou a única a ter o que dizer. Mais ainda, que o que tem a dizer não é necessariamente, por mais importante que seja, a verdade alvissareira por todos esperada (FREIRE, 1996, p.73).

Nesta passagem, Freire levanta questões fundamentais no tocante à educação, muito desafiadoras no cotidiano de um educador que se desafia a educar de modo dialógico. O processo de fala pressupõe um outro que escuta, de modo que este processo demanda uma certa disciplina e rigor, como nos apontou Freire $(1984 ; 1996)$. Controlar o ímpeto da fala, a necessidade de expressar-se naquele exato momento, é abdicar de uma egoísta vontade de manifestação, em prol de um outro que está conduzindo seu raciocínio. Dialogar com o sujeito é isto, o outro que está ali não é mera âncora para que você converse consigo mesmo, e sim, alguém que conjuntamente, ouve e fala, para que possam pronunciar o mundo.

Ao alicerçar-se no diálogo, Freire (1984, 1992) recusará qualquer desrespeito e anulação da diferença. A diferença, que é o escancaramento desse outro sob nós, exige práxis humanista no sentido de mobilizar e nutrir por esse outro diferente, o sentimento de curiosidade e humildade em reconhecê-lo, e, sobretudo, garantir o seu direito de dizer a palavra. "Como posso dialogar se me admito como um homem diferente, virtuoso por herança, diante dos outros, meros isto, em quem não reconheço outros eu" (FREIRE, 2013, p.80).

Saber ouvir, não é novidade, é condição inegociável para qualquer relação minimamente dialógica, mas para Freire é preciso também o respeito irrestrito à fala, ao saber do outro. É necessário ter intacta a dimensão de que o que tenho para falar não é a melhor ideia, a mais completa informação, a real verdade, e sim, mais um olhar, em constante (re)criação, e relação com o olhar do outro, trocando mundos, ressignificando-se, a partir de suas realidades. O educador não pode se colocar como aquele que irá "iluminar" os "sem luz", de modo que trará a verdade inquestionável.

Contudo, vale ressaltar, no âmbito da docência, a dialogicidade não nega a validade de momentos explicativos, narrativos cujo professor expõe ou fala do objeto. "O fundamental é que o professor e alunos saibam que a postura deles, do professor e dos alunos, é dialógica, aberta, curiosa, indagadora e não apassivada, enquanto fala ou enquanto ouve" (FREIRE, 1996, p.72). O que importa para Freire (1996, p.73) é que professor e alunos se assumam "epistemologicamente curiosos". O diálogo tem para Paulo Freire, um papel central como possibilidade de mobilização, de resistência contra todo tipo de dominação, exploração, padronização, de modo que seu componente crítico e libertador não pode ser perdido de vista, ao problematizar o diálogo no processo de ensino e aprendizagem de um contexto de educação escolar.

Em um contexto de opressão, seja no âmbito educacional, ou para além dele, o diálogo humanizador, transformado, é impossível. Entre sujeitos opressores, para Freire (2013) ocorrem palavreados, e não diálogo. Reitera-se aqui, a impossibilidade de diálogo entre opressor e oprimido, sobrando apenas um anti-diálogo opressor e que silencia a palavra de um, em detrimento de outro. Para Freire (2013), no anti-diálogo a relação entre A e B é vertical, em outras palavras, um dialoga para o outro, e jamais, com o outro. $\mathrm{O}$ autor sintetiza o anti-dialógo:

[...] É desamoroso. É acrítico, e não gera criticidade. Exatamente porque desamoroso. Não é humilde. É desesperançoso. Arrogante. Autosuficiente. No antidiálogo quebra-se aquela relação de simpatia entre seus pólos, que caracteriza o diálogo. Por tudo isso o antidiálogo não comunica, faz comunicados (FREIRE, 2013, p.126).

Na sociedade brasileira atual, o anti-diálogo tem tomado lugar mediante intensa polarização política e ideológica que reverbera nas redes sociais e deságua no cotidiano escolar. Movimentos que pedem por uma "Escola Sem Partido" aproveitam desse momento para denunciar uma suposta "ideologização" na educação brasileira. Com isso, defendem uma ilusória neutralidade na educação e confundem o componente político presente na educação, com $\mathrm{o}$ ato sectário de meramente doutrinar.

Acreditamos aqui que apoiadores de movimentos dessa natureza na verdade querem consolidar a ideologia dominante que já é consolidada e manter assim o status quo. Conforme ensina Paulo Freire ao logo de sua obra, toda educação é um ato político de modo que a 
neutralidade na educação é impossível. Desvelar as ideologias é papel fundamental de uma educação emancipadora e libertadora na perspectiva freireana. Desvelá-las não é impô-las, caso contrário a educação se torna anti-dialógica. Ao contrário, desvelar as ideologias é problematizar a educação, estimulando a reflexão de que nos atos educativos, carregam-se implicitamente visões de mundo.

\section{Conclusões}

O presente artigo objetivou perpassar pela obra freireana trazendo a noção de diálogo como categoria conceitual crucial. Educar na perspectiva freireana é fazê-lo para o coletivo e não para o egoísmo, é refletir junto, e não palestrar para aqueles que não sabem, é interferir na sociedade, e não aceitá-la como algo acabado e pronto. O diálogo não é apenas um princípio metodológico, também deve ser compreendido como um princípio educacional que forja uma compreensão pedagógica e de mundo baseado numa epistemologia libertadora.

A docência autoritária, que manipula sutilmente ao invés de estimular a criticidade, é denominada por Freire (2013) como bancária. Antidialógica em essência, essa concepção de docência, pretensamente neutra, nega o viés político da educação, rejeitando seu componente ideológico. A pretensa neutralidade é tudo o que a camada dominante mais deseja no âmbito educacional, para não ter que lidar com o desvelamento do mundo e a possibilidade de emancipação do oprimido.

Assim, setores conservadores defendem uma neutralidade escondendo suas próprias ideologias. Acusam Paulo Freire de fundamentar uma pedagogia da doutrinação, desconhecendo e/ou ignorando sua pedagogia dialógica. $\mathrm{O}$ incômodo causado por Freire é compreensível. Sua pedagogia, muito mais do que mera metodologia de ensino, é pensada com o oprimido e não para ele. Em outras palavras, com Paulo Freire, os silenciados históricos gritam sua palavra, desvelando um mundo classista, desigual, que camufla as ideologias sob aparente neutralidade.

Dialeticamente, a educação não transforma a sociedade, mas ao mesmo tempo não há transformação que consiga ignorar a importância do processo educativo, e aqui vale sempre lembrar: para além da escola enquanto instituição. E, nesse sentido, o professor bem como sua formação, são peças chave para uma educação que se pretende libertadora e na contribuição de uma sociedade aberta à pluralidade e ao diálogo com o outro.

Paulo Freire sempre combateu desde sua primeira obra, a manipulação e doutrinação do ato educativo. Acusá-lo nesses dois quesitos revela o desconhecimento de apoiadores do Movimento "Escola sem Partido", a grande maioria deles, aliás, sem qualquer vínculo com o campo educacional. Conforme buscamos demonstrar, suas críticas vazias optam pela agressão ao invés da fundamentação pelo simples motivo da total incapacidade destes sujeitos de se debruçar seriamente a respeito da obra de Freire para criticá-lo.

Não queremos dizer aqui que Paulo Freire é um teórico perfeito, portador da verdade absoluta e de todos os caminhos para a educação. Isso contradiria as próprias premissas freireanas. Mas certamente, com veemência procuramos demonstrar que as acusações que o "Escola sem Partido" por meio de seu site e das redes sociais, impõe à obra freireana, são injustas e ignorante.

Não é coincidência que movimentos como este ganham força num contexto brasileiro em que jovens passaram a contestar políticas públicas governamentais através das ocupações ocorridas nas escolas públicas. Políticas por essência, tais ocupações revelaram uma parcela da juventude disposta a lutar pelos seus direitos e ávidas por expressar suas palavras de revolta e questionamento.

Para os setores conservadores, tais ocupações eram decorrentes de supostas doutrinações socialistas ocorridas nas escolas públicas, sendo Paulo Freire o mentor intelectual. Do que têm medo esses setores contrários à politização da educação? Seria o medo de uma juventude questionadora que passa a problematizar e desestabilizar as crônicas desigualdades estruturais da sociedade brasileira? Seria o medo de uma juventude que não mais aceita como natural os privilégios de camadas minoritárias da sociedade? Seria o medo de uma educação que os estimulasse a questionar a ordem, ao invés de aceitá-la bovinamente?

O pensamento de Paulo Freire permanece mais vivo do que nunca para uma educação que se pretenda dialógica, humanizadora, emancipadora, que possui, como dizia Freire (2013, p.56), "fé nos homens" e em sua capacidade de "ser mais". Em tempos tão sombrios, cujas vozes que visam anular o outro reverberam cada vez mais intensamente, defender uma pedagogia do diálogo é uma saída possível e urgente para caminharmos rumo a uma sociedade verdadeiramente democrática. 


\section{Notas}

1 Eis uma listagem com os vídeos mais acessados, cuja temática é crítica em relação à obra freireana: "Olavo de Carvalho fala verdades sobre Paulo Freire" (30.427 visualizações): https://www.youtube.com/watch?v=ag-

kqDBFkAE; "O vigarista Paulo Freire" (33.989 visualizações):

https://www.youtube.com/watch?v=I6qb2gMSqg Q; "Seja imbecil aprenda com Paulo Freire" (30.214 visualizações): https://www.youtube.com/watch?v=qlbFieL9rLg. Todos os vídeos foram acessados em 10/04/2017. 2 Ver o debate aqui: https://www.youtube.com/watch?v=J2v7PA1RNq $\mathrm{k} \& \mathrm{t}=22 \mathrm{~s}$. Acessado em: 10/04/2017.

\section{Referências}

AZEVEDO, Reinaldo. Valesca Popozuda numa prova de filosofia e o fim da escola. In: Escola sem partido, 2014. Disponível em:

$<$ http://www.escolasempartido.org/artigos-top/468valesca-popozuda-numa-prova-de-filosofia-e-o-fimda-escola-ou-popozuda-e-a-nossa-schopenhauer> Acessado em: 10 de abril de 2017.

BRASIL. Projeto de Lei n. 193, de 2016. Inclui entre as diretrizes e bases da educação nacional, de que trata a Lei ${ }^{\circ}$ 9.394, de 20 de dezembro de 1996, o "Programa Escola sem Partido". Maio/2016.

ESCOLA SEM PARTIDO. Disponível em: www.escolasempartido.org.br Acessado em: 10 de abril de 2017.

FREIRE, Paulo. Educação como prática da liberdade. Rio de Janeiro: Paz e Terra, 1967.

Educação e Mudança. 2.ed. Rio de Janeiro: Paz e Terra, 1983.

Ação Cultural Para a Liberdade e Outros Escritos. 4.ed. Rio de Janeiro: Paz e Terra, 1984.

Extensão ou Comunicação? 13.ed. Rio de Janeiro: Paz e Terra, 2006.

Pedagogia da autonomia: saberes necessários à prática educativa. Inserir edição. São Paulo: Paz e Terra, 1996.

Pedagogia da Esperança. 11. ed. São
Paulo: Paz e Terra, 1992.

Pedagogia do oprimido. 33 ed. Rio de Janeiro: Paz e Terra, 2013. 1993. . Política e educação. São Paulo: Cortez,

. Professora sim, tia não: cartas a quem ousa ensinar. Inserir edição. São Paulo: Olho D’Água, 1997.

FREIRE, Paulo; SHOR, Ira. Medo e Ousadia - O Cotidiano do Professor. Inserir edição. Rio de Janeiro: Paz e Terra, 1986.

GUEDES, Marília Gabriela de Menezes. Contribuição de Paulo Freire para as políticas e práticas curriculares nos sistemas de ensino. 2012. 233f. Tese apresentada ao Programa de PósGraduação em Educação da Universidade Federal de Pernambuco. Recife: 2012.

MENEZES, Marília Gabriela de; SANTIAGO, Maria Eliete. Contribuição do pensamento de Paulo Freire para o paradigma curricular críticoemancipatório. Pro-Posições. V. 25, n. 3 (75), p. 45-62, set./dez. 2014.

RODRIGUES, Odiombar. Ensino, educação e doutrinação. In: Escola sem partido, 2015.

Disponível em:

<http://www.escolasempartido.org/artigos-top/554ensino-educacao-e-doutrinacao>. Acessado em: 11 de abril de2017.

SAUL, Ana Maria; SILVA, Antônio Fernando Gouveia. O legado de Paulo Freire para as políticas de currículo e para a formação de educadores no Brasil. Revista brasileira Estudos pedagógicos. Brasília, v. 90, n. 224, p. 223-244, 2009.

SCOCUGLIA, Afonso Celso. A História das Idéias de Paulo Freire e a atual crise de paradigmas. 2. ed. João Pessoa: Ed. Universitária / UFPB, 1999.

STERN, Sol. Pedagogia do Opressor. In: Escola sem partido, 2015. Disponível em:

<http://www.escolasempartido.org/doutrina-dadoutrinacao-categoria/502-pedagogia-do-opressor>, Acessado em: 14/04/2017.

STRECK, Danilo. Ecos de Angicos: temas freireanos e a pedagogia atual. Pro-Posições. v.25, n.3 (75), p.83-101, 2014. 


\section{Sobre o autor}

Márden de Pádua Ribeiro: Mestre em Educação - PUCMG. Doutorando em Educação - PUCMG. Professor do curso de Pedagogia da Faculdade de Ciências Sociais Aplicadas de Belo Horizonte. Coordenador do Grupo de Estudo e Pesquisa de Formação Docente (GEPFOR). Integrante da Rede Freireana de Pesquisadores.

Recebido em abril de 2017.

Aprovado em março de 2018. 